\title{
Alteration of protein expression pattern of vascular endothelial growth factor (VEGF) from soluble to cell-associated isoform during tumourigenesis
}

\author{
Ratchada Cressey*1, Onusa Wattananupong1, Nirush Lertprasertsuke ${ }^{2}$ and \\ Usanee Vinitketkumnuen ${ }^{3}$
}

Address: ${ }^{1}$ Department of Associated Medical Science, Chiang Mai University, Chiang Mai, Thailand, 2Department of Pathology, Chiang Mai University, Chiang Mai, Thailand and ${ }^{3}$ Department of Biochemistry, Chiang Mai University, Chiang Mai, Thailand

Email: Ratchada Cressey* - ratchada@chiangmai.ac.th; Onusa Wattananupong - onusa_37@hotmail.com;

Nirush Lertprasertsuke - nlertpra@mail.med.cmu.ac.th; Usanee Vinitketkumnuen - uvinitke@mail.med.cmu.ac.th

* Corresponding author

Published: 04 October 2005

BMC Cancer 2005, 5:128 doi:10.1 |86/147|-2407-5-128

This article is available from: http://www.biomedcentral.com/I47/-2407/5//28

(c) 2005 Cressey et al; licensee BioMed Central Ltd.

This is an Open Access article distributed under the terms of the Creative Commons Attribution License (http://creativecommons.org/licenses/by/2.0), which permits unrestricted use, distribution, and reproduction in any medium, provided the original work is properly cited.

\begin{abstract}
Background: Vascular endothelial growth factor (VEGF) is a potent mitogen for endothelial cells, and its expression has been correlated with increased tumour angiogenesis. Although numerous publications dealing with the measurement of circulating VEGF for diagnostic and therapeutic monitoring have been published, the relationship between the production of tissue VEGF and its concentration in blood is still unclear. The aims of this study were to determine: I) The expression pattern of VEGF isoforms at the protein level in colorectal and lung adenocarcinoma in comparison to the pattern in corresponding adjacent normal tissues 2) The relationship between the expression pattern of VEGF and total level of circulating VEGF in the blood to clarify whether the results of measuring circulating VEGF can be used to predict VEGF expression in tumour tissues.
\end{abstract}

Methods: Ninety-four tissue samples were obtained from patients, 76 colorectal tumour tissues and I 8 lung tumour tissues. VEGF protein expression pattern and total circulating VEGF were examined using western blot and capture ELISA, respectively.

Results: Three major protein bands were predominately detected in tumour samples with an apparent molecular mass under reducing conditions of 18,23 and $26 \mathrm{kDa}$. The $18 \mathrm{kDa}$ VEGF protein was expressed equally in both normal and colorectal tumour tissues and predominately expressed in normal tissues of lung, whereas the 23 and $26 \mathrm{kDa}$ protein was only detected at higher levels in tumour tissues. The 18,23 and $26 \mathrm{kDa}$ proteins are believed to represent the $\mathrm{VEGF}_{121}$, the $\mathrm{VEGF}_{165}$ and the VEGF $_{189}$, respectively. There was a significant correlation of the expression of VEGF $_{165}$ with a smaller tumour size maximum diameter $<5 \mathrm{~cm}(\mathrm{p}<0.05)$, and there was a significant correlation of $\mathrm{VEGF}_{189}$ with advanced clinical stage of colorectal tumours. The measurement of total circulating VEGF in serum revealed that cancer patients significantly $(p<0.00 \mathrm{I})$ possessed a higher level of circulating VEGF ( $108 \mathrm{I} \pm 652 \mathrm{pg} / \mathrm{ml}$ in colorectal and I,25I $\pm 568 \mathrm{pg} / \mathrm{ml}$ in lung) than a healthy volunteer group $(543 \pm$ $344 \mathrm{pg} / \mathrm{ml}$ ). No correlation between the level of circulating VEGF and the pathologic features of tumours was observed.

Conclusion: Our findings indicate that the expression patterns of VEGF isoforms are altered during tumourigenesis as certain isoform overexpression in tumour tissues correlated with tumour progression indicating their important role in tumour development. However, measurement of VEGF in the circulation as a prognostic marker needs to be carefully evaluated as the cell-associated isoform $\left(\mathrm{VEGF}_{189}\right)$, but not the soluble isoform $\left(\mathrm{VEGF}_{121}\right.$ and $\left.\mathrm{VEGF}_{165}\right)$ appears to play important role in tumour progression. 


\section{Background}

VEGF plays a crucial role in tumour expansion by initiating permeabilization of blood vessels, by extravasation of plasma proteins, by invasion of stromal cells, and by causing the sprouting of new blood vessels that supply the tumour with oxygen and nutrients [1]. As a result of alternative splicing, 6 VEGF isoforms of 121, 145, 165, 183, 189 and 206 amino acids are produced from a single gene [2]. Due to differential incorporation of basic residues encoded by exon 6 and 7, VEGF isoforms differ in their heparin-binding properties, membrane association, and secretion [3]. VEGF $_{121}$, which lacks the basic residues of both exons, does not bind heparin-containing cell surface proteoglycan [4], and is freely soluble. VEGF $_{165}$ is also secreted. However, cationic residues in exon 7 enable VEGF $_{165}$ to bind heparin, thus, some remains bound to the cell surface or to extracellular matrix. VEGF 189 which retain both exons, has the highest affinity for heparin and therefore, remains tightly cell associated.

Detection of circulating VEGF has been investigated as a potential serum diagnostic marker for malignant disease and for inflammation [5]. Increased serum concentrations of free VEGF have been measured in various types of cancer, including brain, lung, gastrointestinal, hepatobiliary, renal, and ovarian cancers [6]. However, the relationship between the pattern of the production of VEGF protein isoforms in tumour tissues and their concentration in the circulation is still unclear.

A number of studies have shown that expression of certain VEGF transcripts are correlated with tumour progression. Increased mRNA expression of $\mathrm{VEGF}_{189}$ is correlated with poor prognosis in osteosarcoma [7] and non-small cell lung cancer $[8,9]$, whereas expression of $\mathrm{VEGF}_{121}$ was correlated with lymph node metastasis in primary lung tumours [10]. Although increases of certain VEGF transcripts have been demonstrated to correlate with the progression of various tumours, the actual protein levels of the different VEGF isoforms and their significance during cellular transformation are unknown. Moreover, it has been suggested that elevated protein expression in tumour tissues was mediated by both enhanced transcription [11] and translation [12]. Thus, in order to understand the role of VEGF in tumour progression, it is important to investigate expression of different VEGF isoforms at the protein level during tumourigenesis. To our knowledge, no studies focusing on the VEGF isoform pattern at the protein level and their relationship with respect to total VEGF in the circulation have been reported.

Therefore, the aims of this study were to determine: 1) The protein expression pattern of VEGF isoforms in colorectal and lung tumours in comparison to the corresponding adjacent normal tissues in order to understand whether specific VEGF protein isoforms play an important role during tumourigenesis. 2) The relationship between the expression pattern of VEGF and the level of total circulating VEGF in the blood.

\section{Methods \\ Selection of patients and sample}

Between April 2002 and June 2004, samples were collected from cancer patients at Maharaj Nakorn Chiang Mai Hospital, which comprised 76 colorectal tumours (averaged age was $59 \pm 15.2$ (mean \pm SD), 46 females and 30 males) and 18 non-small cell lung tumours (averaged age was $55 \pm 14.6$, 10 females and 8 males, 9 adenocarcinomas and 9 squamous cell carcinomas). In each case, adjacent normal tissue was collected. These specimens were immediately placed in vials, frozen in embedded medium for the preservation of cell integrity, and stored at $-80^{\circ} \mathrm{C}$ until analyzed. Samples were graded by a pathologist according to the pathological features of the tumours, which included tumour size in maximal diameter, histological grading, lymph node metastasis, distant metastasis, and tumour staging (the AJCC TNM classification).

To avoid pre-analytical sample-to-sample variation due to blood collecting procedures, each blood sample was allowed to clot for at least 4 hrs before collecting serum as it has been reported that the release of VEGF during clotting period would have reached a plateau by this time [13]. Of 94 patients recruited in this study, serums were obtained from 56 cancer patients prior to the operation (38 from colorectal cancer patients, 18 from lung cancer patients). The age range of cancer patients was $58 \pm 12.5$ years and composed of 32 females and 24 males.

Serums were also collected from 47 healthy volunteers with no history of rheumatoid arthritis or recent pregnancy, trauma, surgery (within 1 month) or menstruation (within 1 week) using the same procedure as for the cancer patients so that a comparison could be made. The age range of healthy volunteers was $51 \pm 10.9($ mean \pm SD) years, composed of 20 female and 27 males. All serums were stored at $-70^{\circ} \mathrm{C}$ until analyzed. The study was approved by the ethical committee of the Faculty of Medicine, Chiang Mai University (document number 56/ 2545).

\section{Western blotting}

Western blotting was performed to evaluate the expression of VEGF in each tissue. Frozen tissues were thawed, cut into small pieces and homogenized in SDS lysis buffer (0.5 M Tris-HCl pH 6.8, 2\% SDS (w/v) and 10\% glycerol $(\mathrm{v} / \mathrm{v}))$ containing a protease inhibitors cocktail $(104 \mathrm{mM}$ AEBSF, $0.08 \mathrm{mM}$ aprotinin, $2.2 \mathrm{mM}$ leupeptin, $3.6 \mathrm{mM}$ bestatin, $1.5 \mathrm{mM}$ pepstatin A, $1.4 \mathrm{mM}$ E-64; Sigma, 
a)

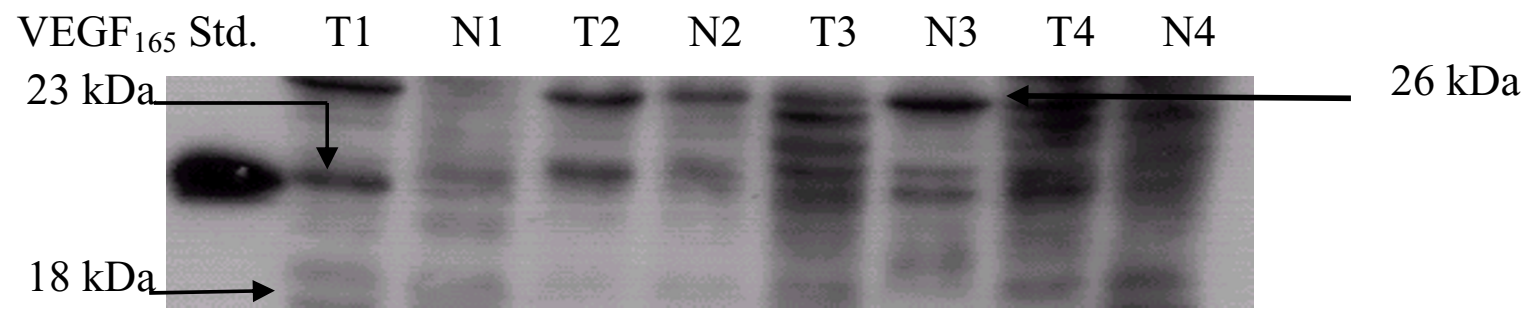

b)

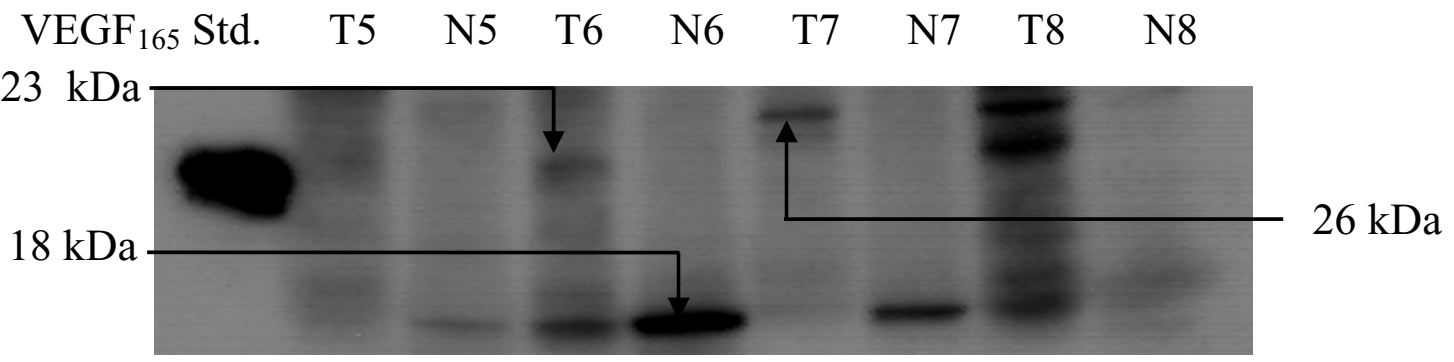

\section{Figure I}

Representative Western blots showing protein expression pattern of VEGF isoform in (a) colorectal and (b) non-small cell lung tumour tissues and their corresponding adjacent normal tissues ( $T$, tumor tissues; $N$, normal tissues).

U.S.A). The tissue homogenate was then centrifuged at $10,000 \mathrm{~g}$ for 15 minutes at $4^{\circ} \mathrm{C}$, after which the supernatant was removed and the protein concentration of the supernatant was estimated using the BCA protein assay kit (PIERCE, U.S.A). Twenty-five micrograms of protein from the tumour tissue and normal tissue from each patient was resolved on a $10 \%$ SDS polyacrylamide gel under reducing conditions and electrotransferred onto a nitrocellulose membrane (Biorad, U.S.A). After blocking with $5 \%$ non-fat milk in TBS containing $0.05 \%$ Tween-20 (TBSTween) for 1 hour, the membrane was incubated with anti-VEGF antibodies (Santa Cruz Biotechnology, Inc., USA, Cat. no. SC-152, dilution 1:1000) for 1 hour. After washing with TBS-Tween, the membrane was incubated for 1 hour at RT with horseradish peroxidase-conjugated goat anti-mouse IgG (Dako, U.S.A). After washing with TBS-Tween, immunoreactive protein was visualized with a chemiluminescence-based procedure using the ECL Plus detection kit according to the manufacturer's protocol (Amersham, U.S.A). In order to examine the equality of protein loaded, the amount of total protein loaded into each lane was examined by staining with coomassie blue.

\section{Measurement of total VEGF in serum}

For the detection of circulating VEGF in serum, enzymelinked immunosorbent assay (ELISA) was performed using two different anti-VEGF antibodies purchased from R\&D system, USA. Briefly, capture antibodies specific for VEGF (R\&D System, cat no. AF293 at concentration 200 $\mathrm{ng} / \mathrm{ml}$ ) was immobilized onto-96-well microtiter plates. Unbound antibody was removed by washing the plate and a blocking reagent was added. Following a wash, recombinant VEGF protein standard $\left(\mathrm{VEGF}_{165}\right)$ diluted in PBS containing 5\% BSA to various concentrations (75$2,500 \mathrm{pg} / \mathrm{ml}$ ), unknown serum and control serum were then incubated with the solid phase antibodies, which capture VEGF. After washing away unbound molecules, a detection antibody specific for VEGF (R\&D System, cat no. MAB293 at concentration $500 \mathrm{ng} / \mathrm{ml}$ ) was added. After incubation and washing, HRP-conjugated anti-mouse immunoglobulin was added. The plate was washed and a TMB substrate solution (Zymed, USA) was added. After 20 minutes, the color development was stopped and the intensity of color was measured using a microtiter plate reader $(450 \mathrm{~nm})$. The color developed in proportion to the amount of bound VEGF. When we measured 20 serum samples twice in two separated assays, the inter-assay 
Table I: Summary of relationship between VEGF isoform expression and pathologic features in colorectal and non-small cell lung cancers ( $p<0.05$ was considered significant)

\begin{tabular}{|c|c|c|c|c|}
\hline \multirow[t]{2}{*}{ Pathologic features } & \multicolumn{4}{|c|}{ VEGF isoform (kDa) } \\
\hline & VEGF 23 kDa & $p$ value $^{\mathrm{a}}$ & VEGF $26 \mathrm{kDa}$ & $p$ value $^{a}$ \\
\hline Colorectal cancer (total 76 cases) & $42(55.3 \%)$ & & $53(69.7 \%)$ & \\
\hline \multicolumn{5}{|l|}{ Gender } \\
\hline Female (46 cases) & $28(60.8 \%)$ & 0.224 & 32 (69.5\%) & 0.968 \\
\hline Male (30 cases) & $14(46.7 \%)$ & & $21(70.0 \%)$ & \\
\hline \multicolumn{5}{|l|}{ Tumour size } \\
\hline$\leq 5 \mathrm{~cm}$ (45 cases) & $30(66.7 \%)^{b}$ & $<0.05$ & $30(66.7 \%)$ & 0.483 \\
\hline$>5 \mathrm{~cm}(3 \mathrm{I}$ cases $)$ & $12(38.7 \%)$ & & $23(74.1 \%)$ & \\
\hline \multicolumn{5}{|l|}{ Histological differentiation } \\
\hline Well (42 cases) & $22(52.4 \%)$ & 0.574 & $28(66.7 \%)$ & 0.517 \\
\hline Moderate or Poor (34 cases) & $20(58.8 \%)$ & & $25(73.5 \%)$ & \\
\hline \multicolumn{5}{|l|}{ Tumour stage grouping } \\
\hline Early stage (I or II) (34 cases) & $23(67.6 \%)$ & 0.09 & $19(55.9 \%)$ & $<0.01$ \\
\hline Late stage (III or IV) (42 cases) & 19 (45.2\%) & & $34(80.9 \%)$ & \\
\hline \multicolumn{5}{|l|}{ Metastasis } \\
\hline No (49 cases) & $31(63.3 \%)$ & 0.059 & 29 (59.2\%) & $<0.01$ \\
\hline Yes (27 cases) & II (40.7\%) & & $24(88.9 \%)$ & \\
\hline Lung cancer (total I 8 cases) & $16(88.9 \%)$ & & $16(88.9 \%)$ & \\
\hline \multicolumn{5}{|l|}{ Gender } \\
\hline Female ( 10 cases) & $8(80.0 \%)$ & 0.477 & $8(80.0 \%)$ & 0.477 \\
\hline Male (8 cases) & $8(100.0 \%)$ & & $8(100 \%)$ & \\
\hline \multicolumn{5}{|l|}{ Tumour size } \\
\hline$\leq 5 \mathrm{~cm}$ (7 cases $)$ & $7(100.0 \%)$ & 0.231 & 7 (100.0\%) & 0.231 \\
\hline > $5 \mathrm{~cm}$ ( II cases) & $9(81.8 \%)$ & & $9(81.8 \%)$ & \\
\hline \multicolumn{5}{|l|}{ Histological differentiation } \\
\hline Well (5 cases) & $4(80.0 \%)$ & 0.490 & $4(80.0 \%)$ & 0.490 \\
\hline Moderate or Poor (1 3 cases) & $12(92.3 \%)$ & & $12(93.3 \%)$ & \\
\hline \multicolumn{5}{|l|}{ Tumour stage grouping } \\
\hline Early stage (I or II) (2 cases) & I (50.0\%) & 0.210 & $0(0.0 \%)$ & $<0.01$ \\
\hline Late stage (III or IV) (16 cases) & $15(93.8 \%)$ & & $16(100 \%)$ & \\
\hline \multicolumn{5}{|l|}{ Metastasis } \\
\hline No (7 cases) & $6(85.7 \%)$ & 1.00 & $5(71.4 \%)$ & 0.137 \\
\hline Yes (II cases) & $10(90.9 \%)$ & & $11(100.9 \%)$ & \\
\hline
\end{tabular}

${ }^{a}$ chi-square test, ${ }^{b}$ percentage in relation to total number of cases in each pathological features

variation ranged between $5-10 \%$ within the same concentration range. The average recovery of the added recombinant $\mathrm{VEGF}_{165}$ ranged between $85-115 \%$, indicating an acceptable level of specificity of the assay.

\section{Statistical analysis}

Total VEGF levels are expressed as mean \pm standard deviation. Differences in the circulating VEGF level of two independent groups were evaluated using the Mann-Whitney test. Correlation between VEGF isoform expression and the pathological features were evaluated using chi-square test. All the statistical evaluations were performed by using the SPSS for Window version 10.0 (SPSS, Inc., Chicago, IL, USA).

\section{Results \\ Pattern of VEGF protein expression in normal and tumour tissues of colon and lung}

The expression pattern of VEGF isoforms in tumour tissues in comparison to normal tissues determined by western blot analysis are shown in Figure 1. Three major protein bands were predominately detected in colorectal and lung tumour samples with an apparent molecular mass under reducing conditions of $18 \mathrm{kDa}, 23 \mathrm{kDa}$, and $26 \mathrm{kDa}$. The $18 \mathrm{kDa}$ VEGF was equally expressed in both 
normal and tumour tissues of colorectal and predominately expressed in normal tissue of lung, whereas the 23 and $26 \mathrm{kDa}$ were only detected at higher levels in tumour tissues of both organs. Expression of the $23 \mathrm{kDa}$ VEGF isoform was observed in $55.3 \%$ ( 42 of 76 patients) of colorectal tumours and $88.9 \%$ (16 of 18 patients) of lung tumour tissues. Whereas, expression of $26 \mathrm{kDa}$ VEGF isoform was detected in $69.7 \%$ (53 of 76 patients) and $88.9 \%$ ( 16 of 18 patients) of colorectal and lung tumour tissues, respectively.

\section{Protein expression patterns of VEGF isoforms in tumour tissues of colon and lung in relation to pathological features}

The two types of cancer were classified according to the pathologic features, which included tumour sizes in maximum diameter, depth of invasion, lymph node metastasis, distant metastasis and histological differentiation. Expression of the VEGF isoforms in relation to the pathological features of colorectal tumours and lung tumours are summarized in Table 1.

No significant difference between gender of the VEGF expression pattern was observed in both types of cancer. In colorectal cancer, it was found that expression of VEGF isoform with molecular weight $23 \mathrm{kDa}$ was significantly correlated with a smaller tumour size (maximum diameter $<5 \mathrm{~cm}, \mathrm{p}<0.05$ ), whereas the $26 \mathrm{kDa}$ VEGF isoform was significantly correlated with advanced clinical stage and metastasis of the tumour $(\mathrm{p}<0.01)$. Expression of the $26 \mathrm{kDa}$ VEGF isoform was also significantly correlated with advanced clinical stage of non-small cell lung cancer $(p<0.001)$. Sixteen (out of 18) lung tumour tissues which overexpressed $26 \mathrm{kDa}$ VEGF were late stage tumours (Table 1). No significant difference of the expression pattern of VEGF between different histology type (adenocarcinoma and squamous cell carcinoma) was observed (data not shown).

\section{Levels of circulating VEGF in cancer patients compared to healthy volunteers and their relationship to pathological features}

Preoperative serum was collected from 56 cancer patients; these included 38 patients with colorectal cancer and 18 with lung cancer. Serum from 47 healthy volunteers was also collected for comparison. The result showed that cancer patients possessed significantly higher level of circulating VEGF than those in healthy volunteers (Figure 2). While level of total circulating VEGF in healthy volunteer was only $543 \pm 344 \mathrm{pg} / \mathrm{ml}$, it was $1081 \pm 652 \mathrm{pg} / \mathrm{ml}$ and $1,251 \pm 568 \mathrm{pg} / \mathrm{ml}$ in patients with colorectal and lung cancer, respectively (Table 2). No significant relationship between the level of circulating VEGF and the pathological features was observed (Table 3). Gender also did not show any impact on circulating level of VEGF (Table 3). In

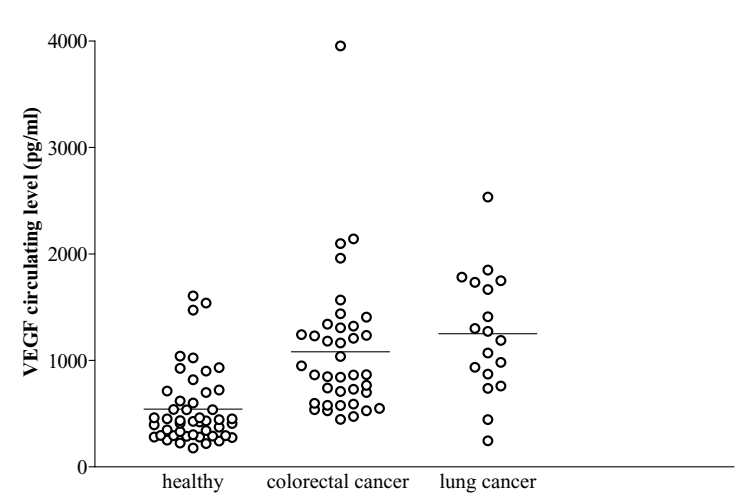

Figure 2

Serum level of circulating VEGF of colorectal and non-small cell lung cancer patients in comparison to healthy volunteers.

addition, none of the VEGF isoforms showed a significant relationship with the serum level of VEGF. Although colorectal cancer patients with overexpression of VEGF 23 $\mathrm{kDa}$, which is believed to be $\mathrm{VEGF}_{165}$ (one of a secretable form of VEGF) in tumour tissues, possessed higher levels of circulating VEGF in serum $(1190 \pm 752 \mathrm{pg} / \mathrm{ml})$ than those possessing undetectable level of $\operatorname{VEGF}_{165}(875 \pm 330$ $\mathrm{pg} / \mathrm{ml})$, it was not statistically significant $(\mathrm{p}=0.207$, Mann-Whitney test).

\section{Discussion}

It has become clear that the growth of solid tumours is dependent on the process of angiogenesis and that VEGF is a central positive regulator of this process. Most VEGFproducing cells appear preferentially to express $\mathrm{VEGF}_{121}$, $\mathrm{VEGF}_{165}$ and $\mathrm{VEGF}_{189}$. In this study, we investigated the expression pattern of the VEGF protein isoform in colorectal tumour tissues and in lung tumour tissues and compared them with the expression pattern of normal tissues from each organ, respectively. Three major protein bands with molecular weight 18, 23 and $26 \mathrm{kDa}$ were predominately detected. The $23-\mathrm{kDa}$ protein band is believed to be the VEGF $_{165}$ as this band was at the same position as the human recombinant $\mathrm{VEGF}_{165}$ protein standard (R\&D System, USA) used in this study. Expression of VEGF $_{145}$ and VEGF $_{206}$ is comparatively rare seemingly restricted to cells of placental origin $[14,15]$. Therefore, protein bands with molecular weight of 18 and $26 \mathrm{kDa}$ are assumed to be $\mathrm{VEGF}_{121}[16,17]$ and $\mathrm{VEGF}_{189}$, respectively.

In colorectal tumours, it was found that VEGF $_{121}$ was expressed equally in both tumour and normal tissues, 
Table 2: Serum level of VEGF in colorectal and non-small cell lung cancer patients in comparison to healthy volunteers ( $p<0.05$ was considered significant)

\begin{tabular}{lccc}
\hline \multicolumn{1}{c}{ Type of sample } & No. of cases & VEGF concentration (pg/ml) & p value \\
\hline Colorectal cancer patients & 38 & $1,081 \pm 652^{\mathrm{b}}$ & $<0.00 \mathrm{I}$ \\
Lung cancer patients & 18 & $1,25 \mathrm{I} \pm 568$ & $<0.00 \mathrm{I}$ \\
Healthy volunteers & 47 & $543 \pm 344$ & \\
\hline
\end{tabular}

aMann-Whitney test, bmean \pm SD

whereas the $\mathrm{VEGF}_{165}$ and $\mathrm{VEGF}_{189}$ were only detected at higher level in tumour tissues. However in lung tumour, VEGF $_{121}$ appeared to be predominately expressed in normal tissues, whereas $\mathrm{VEGF}_{165}$ and $\mathrm{VEGF}_{189}$ were predominately expressed in tumours tissues. Protein expression of $\mathrm{VEGF}_{165}$ correlated significantly with a smaller tumour size, whereas $\mathrm{VEGF}_{189}$ correlated significantly with advanced clinical stage and metastasis of the tumours. Although only 18 lung tumours were investigated in this study, the 26-kDa VEGF isoform was also overexpressed significantly in advanced stage of the tumour (Table 1).

Although the regulation of VEGF expression is becoming well understood, its mode of action, particularly the regulation of expression and distribution of the three primary isoform $\left(\mathrm{VEGF}_{121}, \mathrm{VEGF}_{165}\right.$ and $\left.\mathrm{VEGF}_{189}\right)$, remains unclear. It has been demonstrated that overexpression of smaller isoforms resulted in hemorrhagic events, but the expression of $\mathrm{VEGF}_{189}$ resulted in increased vessel density [18]. In this study we found that overexpression of $\mathrm{VEGF}_{189}$ protein isoform, but not $\mathrm{VEGF}_{121}$ or $\mathrm{VEGF}_{165}$, was associated with advanced tumour stage. Our data is consistent with the previous reports where expression of VEGF $_{189}$ transcripts was correlated with poor prognosis in non-small cell lung, osteosarcoma, renal, colorectal and esophageal cancer $[7-9,19,20]$. It was also suggested that up-regulation of $\mathrm{VEGF}_{189}$ might result in increased angiogenesis, tumour growth and metastasis in a colon cancer cell line [21]. Moreover, $\mathrm{VEGF}_{189}$ has been demonstrated to be a potent permeability factor in vivo [22], supporting the role of this isoform in the control of angiogenesis.

VEGF $_{165}$ has also been demonstrated to play an important role in tumourigenesis. When different isoforms of VEGF were transfected into the VEGF-null cells in isolation and the transfected cells were implanted into nude mice, it was found that $\mathrm{VEGF}_{165}$ was the most prominent isoform that can fully rescue expansion of the angiogenesis-deficient tumour, while $\mathrm{VEGF}_{121}$ and $\mathrm{VEGF}_{189}$ only partially or failed completely to rescue tumour growth, respectively [23]. However, these authors suggested that VEGF iso- forms work in a coordinated fashion to recruit and expand tumour vasculature. In our study we found that although VEGF $_{165}$ was predominately expressed in colorectal tumour tissues, its expression was significantly correlated with smaller tumour size (maximum diameter less than 5 $\mathrm{cm}$.). Although expression of $\mathrm{VEGF}_{121}$ mRNA has been previously reported to be correlated with lymph node metastasis [10] of primary lung cancer and the invasiveness of bladder cancer [24], in our study we found that level of the $18 \mathrm{kDa}$ VEGF protein, which believed to be VEGF $_{121}[16]$, was equally expressed in both normal and tumour tissues of colorectal, and predominately expressed in normal tissues of the lung.

Detection of VEGF has long been known as a potential serum diagnostic marker for malignant diseases. Increased serum VEGF concentrations have been measured in various types of cancer, including, brain, lung, gastrointestinal, hepatobiliary, renal and ovarian cancer [25]. However, the relationship between the pattern of the production of VEGF protein isoforms in tumours and its concentration in the circulation is still unclear. In this study, we determined the expression pattern of VEGF isoforms in tumour tissues in relation to the level of total VEGF in a patient's serum. The comparison of the VEGF level in serum of cancer patients with that of normal volunteers revealed that cancer patients possessed significantly ( $\mathrm{p}<$ 0.001 ) higher levels of VEGF in serum. However, some normal volunteers also possessed quite a high level of VEGF, which may due to the possibility that normal tissues, like lung tissue (Figure 1) can also produce VEGF 121 that is secretable into the circulation. In addition, no significant relationship between level of circulating VEGF and pathologic features was observed.

\section{Conclusion}

Our findings indicate that the expression patterns of VEGF isoforms are altered during tumourigenesis as certain isoform overexpression in tumour tissues correlated with tumour progression indicating their important role in tumour development. However, measurement of circulating VEGF in serum may have limited use as a tumour 
Table 3: Serum level of VEGF in relation to the clinicopathologic features of colorectal and non-small cell lung cancers ( $p<0.05$ was considered significant)

\begin{tabular}{|c|c|c|c|}
\hline Pathological features & No. of cases & VEGF concentration $(\mathrm{pg} / \mathrm{ml})$ & $p$ value $^{a}$ \\
\hline Colorectal tumours & 38 & $\mathrm{I}, 08 \mathrm{I} \pm 652^{\mathrm{b}}$ & \\
\hline \multicolumn{4}{|l|}{ Gender } \\
\hline Female & 22 & $987 \pm 470$ & 0.433 \\
\hline Male & 16 & $|2| 2 \pm 84 \mid$ & \\
\hline \multicolumn{4}{|l|}{ Tumour size } \\
\hline$\leq 5 \mathrm{~cm}$ & 23 & $1134 \pm 727$ & 0.411 \\
\hline$>5 \mathrm{~cm}$ & 15 & $1002 \pm 531$ & \\
\hline \multicolumn{4}{|l|}{ Tumour stage grouping } \\
\hline Early stage & 23 & $1166 \pm 799$ & 0.777 \\
\hline Late stage & 15 & $954 \pm 303$ & \\
\hline \multicolumn{4}{|l|}{ Metastasis } \\
\hline No & 27 & $1132 \pm 749$ & 0.910 \\
\hline Yes & 11 & $961 \pm 304$ & \\
\hline \multicolumn{4}{|l|}{ VEGF 23 kDa } \\
\hline Positive & 25 & $1190 \pm 752$ & 0.207 \\
\hline Negative & 13 & $875 \pm 330$ & \\
\hline \multicolumn{4}{|l|}{ VEGF $26 \mathrm{kDa}$} \\
\hline Positive & 26 & $1125 \pm 720$ & 0.742 \\
\hline Negative & 12 & $989 \pm 486$ & \\
\hline Lung tumours & 18 & $1,25 I \pm 568$ & \\
\hline \multicolumn{4}{|l|}{ Gender } \\
\hline Female & 10 & $1297 \pm 509$ & 0.374 \\
\hline Male & 8 & $1194 \pm 666$ & \\
\hline \multicolumn{4}{|l|}{ Tumour size } \\
\hline$\leq 5 \mathrm{~cm}$ & 7 & $|304 \pm 66|$ & 0.762 \\
\hline$>5 \mathrm{~cm}$ & 11 & $1217 \pm 532$ & \\
\hline \multicolumn{4}{|l|}{ Tumour stage grouping } \\
\hline Early stage & 2 & $716 \pm 666$ & 0.206 \\
\hline Late stage & 16 & $|3| 8 \pm 54 \mid$ & \\
\hline \multicolumn{4}{|l|}{ Metastasis } \\
\hline Yes & 8 & $1125 \pm 655$ & 0.556 \\
\hline No & 10 & $|33| \pm 522$ & \\
\hline \multicolumn{4}{|l|}{ VEGF 23 kDa } \\
\hline Positive & 16 & $1190 \pm 574$ & 0.160 \\
\hline Negative & 2 & $|74| \pm 9.8$ & \\
\hline \multicolumn{4}{|l|}{ VEGF 26 kDa } \\
\hline Positive & 16 & $1224 \pm 590$ & 0.482 \\
\hline Negative & 2 & $1468 \pm 395$ & \\
\hline
\end{tabular}

a Mann-Whitney test, bmean \pm SD

marker. This may be due to the following reasons: 1) The VEGF isoform that appeared to be significantly correlated with tumour progression is $\mathrm{VEGF}_{189}$, which is the cellassociated isoform, is not soluble. 2) Some normal tissues, i.e. lung (as shown in Figure 1), expressed high-level VEGF isoforms $\left(\mathrm{VEGF}_{121}\right)$ that secreted into the circulation. 3) Expression of some secretable VEGF isoforms $\left(\mathrm{VEGF}_{165}\right)$ was negatively correlated with the progression of tumour size, thus its level may not positively indicate the stage of the tumour. 4) As has been previously reported, other physiologic and pathologic condition, i.e., pregnancy, RA and cardiovascular diseases can also cause the induction the circulating level of VEGF $[26,27]$.

\section{Competing interests}

The author(s) declare that they have no competing interest.

\section{Authors' contributions}

RC designed and sought funding for the study, initiated coordination, performed statistical analysis and drafted the manuscript. OW recruited healthy volunteers and per- 
formed the ELISA and western blot analysis. NL recruited cancer patients and carried out the pathological feature examination. UV participated in design of the study and coordination. All authors read and approved the final manuscript.

\section{Acknowledgements}

This work was sponsored by the Thailand Research Fund (Grant no. MRG45800I3) and partly supported by the Thailand National Center for Genetic Engineering and Biotechnology (BIOTEC), National Science and Technology Development Agency (NSTDA).

\section{References}

I. Ruegg C, Meuwly JY, Driscoll R, Werffeli P, Zaman K, Stupp R: The quest for surrogate markers of angiogenesis: a paradigm for translational research in tumor angiogenesis and anti-angiogenesis trials. Curr Mol Med 2003, 3:673-691.

2. Ferrara N, Houck KA, Jakeman LB, Winer J, Leung DW: The vascular endothelial growth factor family of polypeptides. J Cell Biochem I99|, 47:21|-218.

3. Park JE, Keller GA, Ferrara N: The vascular endothelial growth factor (VEGF) isoforms: differential deposition into the subepithelial extracellular matrix and bioactivity of extracellular matrix-bound VEGF. Mol Biol Cell 1993, 4:13|7-1326.

4. Cohen T, Gitay-Goren H, Sharon R, Shibuya M, Halaban R, Levi BZ, Neufeld G: VEGFI2I, a vascular endothelial growth factor (VEGF) isoform lacking heparin binding ability, requires cellsurface heparan sulfates for efficient binding to the VEGF receptors of human melanoma cells. J Biol Chem 1995, 270: $11322-11326$

5. Bottomley MJ, Webb NJ, Watson CJ, Holt L, Bukhari M, Denton J, al : Placenta growth factor (PIGF) induces vascular endothelial growth factor (VEGF) secretion from mononuclear cells and is co-expressed with VEGF in synovial fluid. Clin Exp Immunol 2000, II 9:182-188.

6. Jelkmann W: Pitfalls in the measurement of circulating vascular endothelial growth factor. Clin Chem 2001, 47:617-623.

7. Lee YH, Tokunaga T, Oshika Y, Suto R, Yanagisawa K, Tomisawa M, Fukuda H, Nakano H, Abe S, Tateishi A, Kijima H, Yamazaki H, Tamaoki N, Ueyama $Y$, Nakamura M: Cell-retained isoforms of vascular endothelial growth factor (VEGF) are correlated with poor prognosis in osteosarcoma. Eur J Cancer 1999, 35:1089-1093.

8. Oshika Y, Nakamura M, Tokunaga T, Ozeki Y, Fukushima Y, Hatanaka $\mathrm{H}$, Abe Y, Yamazaki H, Kijima H, Tamaoki N, Ueyama Y: Expression of cell-associated isoform of vascular endothelial growth factor 189 and its prognostic relevance in non-small cell lung cancer. Int I Oncol 1998, I 2:54|-544.

9. Yuan A, Yu CJ, Kuo SH, Chen WJ, Lin FY, Luh KT, Yang PC, Lee YC: Vascular endothelial growth factor 189 mRNA isoform expression specifically correlates with tumor angiogenesis, patient survival, and postoperative relapse in non-small-cell lung cancer. J Clin Oncol 200I, 19:432-44I.

10. Ohta $Y$, Watanabe $Y$, Murakami S, Oda M, Hayashi $Y$, Nonomura A, Endo $Y$, Sasaki T: Vascular endothelial growth factor and lymph node metastasis in primary lung cancer. $\mathrm{Br} J$ Cancer 1997, 76: $104 \mid-1045$.

II. Shweiki D, Itin A, Soffer D, Keshet E: Vascular endothelial growth factor induced by hypoxia may mediate hypoxia-initiated angiogenesis. Nature 1992, 359:843-845.

12. Kelvis CH, De Benedetti A, Payne DK, Coe LL, Laroux FX, Alexandra JS: Translational regulation of vascular permeability factor by eukaryotic initiation factor 4E: implication for tumor angiogenesis. Int J Cancer 1996, 65:785-790.

13. Dittadi R, Meo S, Fabris F, Gasparini G, Contri D, Medici M, Gion M: Validation of blood collection procedures for the determination of circulating vascular endothelial growth factor (VEGF) in different blood compartments. Int I Biol Markers 200I, 16:87-96.

14. Anthony FW, Wheeler T, Elcock Cl, Pickett M, Thomas Ej: Short report: identification of a specific pattern of vascular endothelial growth factor mRNA expression in human placenta and cultured fibroblasts. Placenta 1994, 15(5):557-56I.

15. Cheung N, Singh M, Ebaugh MJ, Brace RA: Vascular endothelial growth factor gene expression in ovine placenta and fetal membrane. Am J Obstet Gynecol 1995, 173:753-759.

16. Mohanraj D, Olson T, Ramakrishnan S: A novel method to purify recombinant vascular endothelial growth factor (VEGF I II) expressed in yeast. Biochem Biophys Res Commun 1995, 215:750-756.

17. Nishimura S, Maeno N, Matsuo K, Nakajima T, Kitajima I, Saito H, Maruyama I: Human lactiferous mammary gland cells produce vascular endothelial growth factor (VEGF) and express the VEGF receptors, Flt-I AND KDR/FIk-I. Cytokine 2002, I8:191-198.

18. Cheng SY, Nagane M, Huang HS, Cavenee WK: Intracerebral tumor-associated hemorrhage caused by overexpression of the vascular endothelial growth factor isoforms VEGFI2I and VEGFI 65 but not VEGF 189. Proc Natl Acad Sci U S A 1997 , 94: $1208|-| 2087$.

19. Tokunaga T, Oshika Y, Abe Y, Ozeki Y, Sadahiro S, Kijima H, Tsuchida T, Yamazaki H, Ueyama Y, Tamaoki N, Nakamura M: Vascular endothelial growth factor (VEGF) mRNA isoform expression pattern is correlated with liver metastasis and poor prognosis in colon cancer. BrJ Cancer 1998, 77:998-1002.

20. Tomisawa M, Tokunaga T, Oshika $Y$, Tsuchida T, Fukushima $Y$, Sato H, Kijima H, Yamazaki H, Ueyama Y, Tamaoki N, Nakamura M: Expression pattern of vascular endothelial growth factor isoform is closely correlated with tumour stage and vascularisation in renal cell carcinoma. Eur J Cancer I999, 35:133-137.

21. Koura AN, Liu W, Kitadai Y, Singh RK, Radinsky R, Ellis LM: Regulation of vascular endothelial growth factor expression in human colon carcinoma cells by cell density. Cancer Res 1996, 56:389I-3894.

22. Ancelin M, Buteau-Lozano H, Meduri G, Osborne-Pellegrin M, Sordello S, Plouet J, Perrot-Applanat M: A dynamic shift of VEGF isoforms with a transient and selective progesterone-induced expression of VEGFI89 regulates angiogenesis and vascular permeability in human uterus. Proc Natl Acad Sci U S A 2002, 99:6023-6028.

23. Grunstein J, Masbad JJ, Hickey R, Giordano F, Johnson RS: Isoforms of vascular endothelial growth factor act in a coordinate fashion To recruit and expand tumor vasculature. Mol Cell Biol 2000, 20:7282-729I.

24. Li NC, Kanda K, Fukumori T, Inoue $Y$, Nishitani M, Kanayama $H$, Kagawa S: Expression of vascular endothelial growth factor isoforms and platelet-derived endothelial cell growth factor in bladder cancer. Urologic Oncology 2000, 6:10-15.

25. Kondo S, Asano M, Matsuo K, Ohmori I, Suzuki H: Vascular endothelial growth factor/vascular permeability factor is detectable in the sera of tumor-bearing mice and cancer patients. Biochim Biophys Acta 1994, I 22 I:2 I I-214.

26. Afuwape $A O$, Kiriakidis S, Paleolog EM: The role of the angiogenic molecule VEGF in the pathogenesis of rheumatoid arthritis. Histol Histopathol 2002, 17:96I-972.

27. Zygmunt M, Herr F, Munstedt K, Lang U, Liang OD: Angiogenesis and vasculogenesis in pregnancy. Eur J Obstet Gynecol Reprod Biol 2003, I I 0 SuppI I:SI0-8.

\section{Pre-publication history}

The pre-publication history for this paper can be accessed here:

\section{http://www.biomedcentral.com/1471-2407/5/128/pre} pub 